\title{
Motivations towards Learning English: The Case of Jordanian Gifted Students
}

\author{
Fadi Maher Al-Khasawneh ${ }^{1, *} \&$ Mohammad Ahmad Al-Omari ${ }^{1}$ \\ ${ }^{1}$ Faculty of Arts and Educational Sciences, Ajloun National University, Jordan \\ *Corresponding author: Faculty of Arts and Educational Sciences, Ajloun National \\ University, Jordan. E-mail: fadialkhasawneh@yahoo.com
}

Received: May 27, 2015 Accepted: June 5, 2015 Published: June 26, 2015

doi:10.5296/ije.v7i2.7699 URL: http://dx.doi.org/10.5296/ije.v7i2.7699

\begin{abstract}
The present study aimed at investigating the motivational orientations of Jordanian gifted school students in Ajloun governorate. For this purpose, 51 students from King Abdullah II in Ajloun governorate participated in this study. Data was collected through a questionnaire contained 20 items asking about the motivational level and orientation of learners. The questionnaire was adapted from Gardner's (1985) AMTB (Attitude, Motivation Test Battery) questionnaire. The researchers used descriptive statistics for identifying the students' level of motivation towards learning English. Independent samples T-test was used to investigate the differences in the level of motivation according to gender. The findings revealed that the students were highly motivated towards learning English language with higher scores reported for the sake of instrumental motivation. Female students reported higher level of motivation than male students with no statistically significant differences recorded concerning this. Based on the results, some of the implications were presented and discussed.
\end{abstract}

Keywords: Motivations, Gifted students, Integrative, Instrumental, EFL 


\section{Introduction}

English language is spoken and written by billions of people worldwide. The importance of being proficient in English language is undeniable and it is necessary to be successful especially in academic life. English is extensively used in several fields such as economics, tourism, arts, sciences, mass media, and politics (Che Mat and Yunus, 2014). Brown (2000) points out that learners should be engaged to all English language skills (i.e. reading, listening, writing, and speaking) to successfully master English language. The process of learning any language is said to be affected by several factors such as attitude, aptitude, and motivation. The motivation factor is one of the most important factors that could determine the success of learning a second or a foreign language (Oxford and Shearing, 1994). The study of motivation as a determiner for L2 successful learning began with Gardner and Lambert's sociolinguistic study of English-speaking students studying French in 1959. Since then, a considerable number of research works have been carried out to explore the role of motivation in L2 learning (e.g. Gardner, 1985, 2001; Gardner and Lambert, 1959, 1972; Gardner, Smythe, and Clement, 1979). The aforementioned researchers have studied the attitude and motivation and their correlation with learners' linguistic performance as factors that determine L2 successful learning. These studies suggested that learners must be psychologically willing to acquire symbolic elements of a different ethno-linguistic community, and to impose elements of another culture into one's own life space (Agnihotri and Khanna 1994). In addition, there was a general consensus among these studies that influential way to get a clear picture to learning process is to study the learners' attitudes and motivations toward learning English language.

\section{Status of English in Jordan}

The history of English in Jordan can be traced back to 1920. According to Bader (1995), Jordanians started to be exposed to the English language towards the end of World War I, as a result of the British colonization of Jordan. The British colonization of Jordan was the major reason of importing English language into Jordanian society. Since then, English has gained an extreme significance through formal tuition and second language learning. Presently, English plays an important role in the Jordanian education system and students are expected to communicate effectively in institutions where English is the medium of instruction. According to Jafar (2008), English is taught as a foreign language all through the entire span of the school years from Kindergarten to the second secondary grade, and it is considered as an obligatory subject for the school curriculum. On the other hand, English language is necessary to communicate with the world, social development, acquisition of new technology, and education (Zughoul, 2003). The English status in Jordan falls within the expanding circle in which English is a foreign language and its use is predictably growing. According to Kachru (1992), the status of English worldwide contains three main circles. The inner circle is related to countries in which English is the mother tongue; the outer circle involves countries in which English is a second language; and the expanding circle includes countries in which English is a foreign language. The main reasons for teaching English in 
Jordan are instrumental and educational reasons. English is considered as a prerequisite for most careers and jobs; the Ministry of Education in Jordan gives considerable attention to English teaching especially to the English curriculum and teachers' training (Jafar, 2008). At the university level, English departments in the Jordanian universities have an excellent reputation and are considered as the best among other Arab universities (Hazaymeh, 2004). As a consequence, the central objective of teaching English in Jordan is to empower learners to communicate effectively with others at formal and personal levels (Jafar, 2008).

\section{The Theory of Motivation}

Motivation has long been recognized as an important factor in the education and social psychology fields. It is also important in anticipating second or foreign language achievement and success (Zahran, 1990). However, it is not easy to provide simple definition for motivation, hence; the idea of motivation has been defined and viewed differently by different schools. Dejnozka and Kapel (1991) defined motivation as "a psychological concept in human behavior that describes a predisposition reward a particular" (p.61). Gardner (2006, p.242) views motivation as "a very complex phenomenon with many facets". As mentioned earlier, the motivation idea has been viewed by different schools of thoughts. For instance, the cognitivists view motivation as an idea which is more related to the learner's decision to learn. Keller (1983) states that motivation is the "choices people make as to what experiences or goals they approach or avoid, and the degree of effort they exert in that respect" (p. 389). The behaviorism school views motivation as "quite simply the anticipation of reward, (Brown, 2000, p. 160)". The constructivists put more emphasis on the individual decisions and social contexts. Despite the variances in defining the concept of motivation, but the three schools agree that motivation is related to "needs" concept, that is motivation is "the fulfillment of needs is rewarding, requires choices, and in many cases must be interpreted in a social context" (Gardner, 2006, p.242). The motivation that learners have might determine the success of learning a second or a foreign language. Brown (2000) claims that motivated learners are more successful compared to unmotivated learners. In a similar vein, Gardner (2006) states that learners with a high level of motivation will perform better than learners with a low level of motivation. He adds that "if one is motivated, s/he has reasons (motives) for engaging in the relevant activities, expends effort, persists in the activities, attends to the tasks, shows desire to achieve the goal and enjoys the activities" (Gardner, 2006, p. 243).

\subsection{Types of Motivation}

Previous studies concerned about motivation in learning a second or a foreign language have made a clear difference between two types of motivation namely, integrative versus instrumental motivation. Gardner and Lambert (1972) clarify that integrative motivation is learning a language for personal sakes and cultural enrichment; while instrumental motivation is learning a language to gain more direct and practical purposes. Lucas et.al (2010) define integrative motivation as the desire to learn L2 to have contact with members from L2 community; while instrumental motivation for them was defined as the desire to learn L2 to reach practical purposes such as academic success and job advancement. In other 
words, instrumentally motivated learners own very specific goals for L2 learning such as listening to radio, reading books, or watching TV programs. On the other hand, integratively motivated learners have got different goals such as knowing the culture, norms, and traditions of the L2 community. Masgoret and Gardner (2003) states that integratively motivated learners have the willing to know the culture of foreign countries, and the status of that foreign language for them is similar to their native language's status. Noels (2001) points out that learners' motivation to language learning consists of several variables such as desire to reach their goals, effort, and attitudes to learn that language. Crookes, and Schmidt (1991) claim that integrative motivation is more important in sustaining long-term success in L2 learning.

\subsection{Motivation and Gender}

An extensive research have been done to investigate the relationship between L2 learning and gender. Gender has long seen as a factor that could affect the learning of second or foreign language. Most of these studies concluded that there are differences in L2 learning according to gender with superiority to female learners. Williams, Burden, and Lanvers (2002) found that female British elementary students had a higher level of motivation compared to their male counterparts. Dornyei et al. (2006) conducted a study among Hungarian school students to investigate the motivation differences in L2 learning taking into consideration gender variable. The results showed significant motivational differences in favor of female students. Ghazivini and Khajehpour's (2011) study reported that Iranian Secondary students had higher motivation to learn English than male students. In spite of the frequent study results that showed female superiority in L2 motivation, a few studies indicated opposite results. Al-Bustan and Al-Bustan (2009) showed negative attitude towards learning English among Kuwaiti female students, while negative attitudes were not found among male students in this study. Polat (2011) carried out a study to investigate the motivation towards learning Turkish language among middle and high school students in Turkey. The results of this study revealed that male students scored significantly higher motivation towards learning Turkish. The results also showed that male students were more autonomous in identifying and manipulating their own learning.

It is clear that gender differences in L2 motivation is a complex phenomenon, and the research results about this relationship were inconsistent. Therefore, researchers attempted to explain these differences according to social environment factors. Kobayashi (2002) referred to the Japanese society, which considers English learning as a female dominant choice at schools and a tool to assist females to be away from a society which suffers from women marginalization. Dornyei (2005) explained that the reason for male students to score lower than female students on the motivation of learning French can be attributed to social factors. They added that male students perceive French as a feminine language and it is more appropriate for female students to learn. In a study conducted by Ryan (2009), the results revealed that the reason for female learners' high score towards learning English can be attributed to freedom reason. Female learners believe that using English allows them to be more expressive compared to Japanese language which has restrictive features for female speakers. That is to say, causes of gender differences in L2 motivation are mainly social 
causes not only neurobiological.

\subsection{Related Studies on Motivation and Language Learning}

A number of studies have been carried out in order to investigate the level and types English language learning motivation (Qashoa, 2006; Kyriacou and Zhu, 2008; Choosri and Intharaska, 2011; Kitjaroonchai and Kitjaroonchai 2012; Tahaineh and Daana, 2013; Che Mat and Yunus, 2014). Qashoa (2006) investigated the motivation of learning English language in the UAE secondary schools. The findings of this study showed that the students reported higher degree of instrumental motivation than the integrative one. This is because students stated that being proficient in English might lead to obtain a better job with high paying. Kyriacou and Zhu (2008) examined the Chinese school students' motivation towards learning English language. The findings revealed that the students' learning motivation is dominated by life and job-based reasons, while they reported lower degree of integrative learning motivation. Choosri and Intharaska (2011) explored the relationship between English learning motivation and language learning achievement among Thai vocational students. The results of this study revealed higher degree of instrumental motivation compared to integrative motivation. The results also showed a correlation between learning motivation and English language learning achievement. Kitjaroonchai and Kitjaroonchai (2012) investigated the level and types of English language learning motivation that Thai university students hold. The findings unveiled that the students indicated slightly higher degree of instrumental than integrative ones. In Jordan, Tahaineh and Daana (2013) conducted a study to explore the motivation orientations of the Jordanian EFL female undergraduate students at Al Balqa' Applied University-Princess Alia University College. The findings revealed that the students indicated a high degree of instrumental motivation. They also pointed out that they learn English language for academic reasons. Finally, Che Mat and Yunus (2014) investigated the learning motivation of FELDA primary school students in Malaysia. The findings concluded that the students were highly motivated and instrumentally motivated to learn English.

\subsection{Giftedness}

The term "giftedness" has received different definitions by several scholars and previous studies. Feldhusen (1986) defined giftedness as having extraordinary talent which leads to perform a remarkably high level of achievement when compared with others. Kokot (1999) states that giftedness is having awareness, high sensitivity, and outstanding skills to understand cognitive and emotional experiences related to their colleagues. According to Maker and Nielson (1996), gifted students have a special and extraordinary ability to understand fast and easily, comprehend the knowledge, obtain, continue, integrate and improve the skill to face any learning hindrance they might have. Motivation is one of the affective factors that is responsible for giftedness (Brophy, 1998). Motivation is a factor helps learners to demonstrate specific behaviors under specific circumstances (Kokturk, 2000). Generally, motivation can be considered as the motive to adjust behaviors in a way that may suit psychological and physical activities (Budak, 2003). Learners who have high motivation tend to show more determination and effort in class tasks and activities compared to learners 
with low motivation (Maker and Nielson, 1996). Learners motivation can be affected by goal-orientation, self-efficacy, anxiety, task value, learning goals, and learning strategies. Motivation is a key concept in education and if it increases, the effectiveness of education will increase and vice versa. Gifted students are seen as high motivated students who focus on individual learning, persistence, internal locus of control, task commitment, and perceptual strength (Dun and Griggs, 1985). Therefore, it is advised to conduct more studies in order to compare gifted and non-gifted students' motivational orientation due to its importance in facilitating the learning process.

\section{Problem Statement}

As mentioned earlier, motivation is one of the important factors that leads to success in language learning, and it is one of the determiners of learning a second or foreign language (Dornyei, 2005). It would be difficult for demotivated learners to learn any language including English language. Hence, identifying the learners' goals and motivations would help the curriculum designers and educational decision-makers to take the necessary considerations in order to improve the learners' proficiency in English language. Many studies have been carried out to examine the level and types of motivation among primary, high, and university students due to its importance to maximize the positive outcomes. However, very few studies have been conducted to investigate the motivational orientations in the Jordanian context. Also, there are few studies focused on the level and types of motivation among gifted learners as they have extraordinary learning abilities. These abilities might lead to a difference in motivation and orientation in learning English language. Therefore, this paper comes to discuss the motivational orientations of Jordanian gifted school students. The present study complements other studies in this field and may provide another avenue for examining the language learning motivation in the Jordanian context.

\section{The Study}

The present descriptive study attempts to investigate the motivational orientations of gifted Jordanian students at high schools. The motivational orientations include the level, types, and the motivation differences in learning English language according to gender.

\subsection{Research Questions}

1) What is the level of motivation towards learning English of gifted students at Jordanian high schools?

2) Are the students motivated instrumentally or integratively towards learning English?

3) Is there any statistical significant differences in the motivation towards learning English according to gender? 


\subsection{Participants}

The participants of this study include 51 EFL high school students. These students were studying at King Abdullah School for gifted students, Ajloun governorate during the academic year 2014/2015. The participants consisted of 33 male students and 18 female students. The participants' age ranges from 17-18 years old. The following table illustrates the demographic distribution of the participants.

Table 1. Demographic Distribution of the Participants

\begin{tabular}{cccccc}
\hline & Frequency & Percent & Valid Percent & Cumulative Percent \\
\hline \multirow{2}{*}{ Valid } & Male & 33 & 64.7 & 64.7 & 64.7 \\
& Female & 18 & 35.3 & 35.3 & 100.0 \\
& Total & 51 & 100.0 & 100.0 & \\
\hline
\end{tabular}

\subsection{Instrumentation}

A modified version of Gardner's (1985) AMTB (Attitude, Motivation Test Battery) questionnaire along with the demographical questionnaire were administered to the selected participants. The questionnaire consisted of 20 items measuring the students' motivation towards learning English language. The first 10 items measure the students' integrative motivation, while the items 11-20 measure the students' instrumental motivation towards learning English language. The questionnaire was a 5-point Likert Scale ranging from 'Strongly Agree' to 'Strongly Disagree'. The questionnaire items were translated into Arabic to avoid any misunderstanding and to get more accurate responses from the students. To ensure the validity and reliability of the questionnaire, the translated version of the questionnaire was checked by an Arabic language professor at Ajloun National University to ensure the clarity of the items, and to guarantee the students' full understanding of the questionnaire items. It is worth mentioning that no major corrections were made to the wording of the questionnaire. Regarding the reliability of the questionnaire, the AMTB was found to be reliable as it was used in a number of the previous studies which focused on motivation (Qashoa, 2006; Kyriacou and Zhao, 2008; Choosri and Intharaska, 2011; Kitjaroonchai and Kitjaroonchai 2012; Tahaineh and Daana, 2013; Che Mat and Yunus, 2014). Also, the reliability of the questionnaire was statistically checked using SPSS software and the Cronbach Alpha was .861 which is considered acceptable to administer the questionnaire.

\subsection{Research Procedure}

For the purpose of administering the questionnaire at King Abdullah School for gifted student, a permission was obtained from the directorate of education, Ajloun governorate. Upon approval, the research conducted the survey and the questionnaires were administered with assistance from one of the advisors who work at Ajloun National University. The questionnaires took 10 minutes to be filled and completed. The students were told that no names will be given and the results of the research will be used for academic purposes. 


\subsection{Data Analysis}

The responses of the participants to the questionnaire were analyzed descriptively using the Statistical Package for Social Sciences (SPSS) version 17.0. The descriptive results include means and standard deviations to indicate the level and types of motivational orientations of gifted students at Jordanian high schools. The students were decided to be highly motivated at the mean from 3.5-5.0, medium motivation from 2.5-3.49, and low motivated from 1.0-2.49. Independent samples T-Test was used to investigate the differences in motivation according to gender.

\section{Findings}

The findings will be presented according to the research questions mentioned earlier in the present study.

\subsection{Level of Motivation of Jordanian Gifted Students}

The present section aims at obtaining answers regarding the first research question: What is the level of motivation towards learning English of gifted students at Jordanian high schools? In order to get answers for the first research question, mean and standard deviations were calculated to identify the level of motivation of gifted Jordanian high schools students (see table 2).

Table 2. Level of Motivation of Jordanian Gifted Students

\begin{tabular}{cccccc}
\hline & $\mathrm{N}$ & Minimum & Maximum & Mean & Std. Deviation \\
\hline Motivation & 51 & 2.50 & 4.95 & 4.0755 & .50896 \\
Valid N (listwise) & 51 & & & & \\
\hline
\end{tabular}

As illustrated in Table 2, the overall mean score of learning motivation was 4.07. This result means that gifted students at Jordanian schools are highly motivated towards learning English. Next section presents the level of integrative and instrumental motivations towards learning English.

\subsection{Level of Integrative and Instrumental Motivations of Jordanian Gifted Students}

This section provides analysis to the second research question: Are the students motivated instrumentally or integratively towards learning English? The analysis procedures include means and standard deviations for each type of motivation along with the items of integrative and instrumental motivations (see Tables 3-5). 
Table 3. Integrative and Instrumental Motivations of Jordanian Gifted Students

\begin{tabular}{lccccc}
\hline & $\mathrm{N}$ & Minimum & Maximum & Mean & Std. Deviation \\
\hline Integrative & 51 & 1.80 & 4.90 & 3.8000 & .63561 \\
Instrumental & 51 & 2.80 & 5.00 & 4.3510 & .51744 \\
Valid N (listwise) & 51 & & & & \\
\hline
\end{tabular}

Based on the data obtained from the questionnaire, it is apparent that the students are instrumentally motivated towards learning English $(M=4.35)$. However, the students showed integrative motivation towards learning English $(M=3.80)$. The mean score of instrumental motivation was considerably higher compared to the integrative mean score. Therefore, it can be said that Jordanian gifted school students are instrumentally motivated towards toward learning English language. The following tables present the mean scores of integrative and instrumental motivational items as appeared of the questionnaire.

Table 4. Descriptive Statistics of Integrative Motivation Items

Std.

\begin{tabular}{|c|c|c|c|c|c|}
\hline & $\mathrm{N}$ & Minimum & Maximum & Mean & Deviation \\
\hline $\begin{array}{l}\text { Learning English is important to me because I can understand the } \\
\text { cultures and traditions of native speakers of English. }\end{array}$ & 51 & 1.00 & 5.00 & 4.2941 & .85543 \\
\hline $\begin{array}{l}\text { Learning English is important to me because I can understand } \\
\text { English stories, novels, and literature. }\end{array}$ & 51 & 1.00 & 5.00 & 3.6471 & 1.18023 \\
\hline $\begin{array}{l}\text { Learning English helps me to better understand the ways of life of } \\
\text { native speakers of English. }\end{array}$ & 51 & 1.00 & 5.00 & 4.0392 & .87088 \\
\hline Learning English helps me to easily make friends with foreigners. & 51 & 2.00 & 5.00 & 4.0588 & 90359 \\
\hline $\begin{array}{l}\text { Learning English helps me to learn about values and beliefs of } \\
\text { native speakers of English. }\end{array}$ & 51 & 1.00 & 5.00 & 3.7647 & .97135 \\
\hline $\begin{array}{l}\text { Learning English helps me to be open-minded and friendly like } \\
\text { native English speakers. }\end{array}$ & 51 & 1.00 & 5.00 & 3.2941 & 1.50059 \\
\hline $\begin{array}{l}\text { Learning English helps me to understand the American and British } \\
\text { jokes. }\end{array}$ & 51 & 1.00 & 5.00 & 3.3529 & 1.23002 \\
\hline $\begin{array}{l}\text { Learning English helps me to understand the American and British } \\
\text { movies and talk-shows. }\end{array}$ & 51 & 1.00 & 5.00 & 4.2745 & .85037 \\
\hline $\begin{array}{l}\text { Learning English helps me to read English books, articles, } \\
\text { newspapers, and magazines. }\end{array}$ & 51 & 2.00 & 5.00 & 4.4118 & .85268 \\
\hline I Learn English because I like English movies and songs. & 51 & 1.00 & 5.00 & 2.8627 & 1.38592 \\
\hline Valid N (listwise) & 51 & & & & \\
\hline
\end{tabular}


As revealed in Table 4, the students reported higher integrative motivation in questions 9, 8, 1 (i.e. learning English helps me to read English books, articles, newspapers, and magazines, learning English is important to me because I can understand the cultures and traditions of native speakers of English, and learning English helps me to understand the American and British movies and talk-shows. The lowest mean scores reported by the students were questions 10, 6, 7 (i.e. I Learn English because I like English movies and songs, learning English helps me to be open-minded and friendly like native English speakers, and learning English helps me to understand the American and British jokes). Generally, the students reported high integrative motivation towards learning English as it helps them to communicate with English native speakers and to know their culture and traditions. The following table presents the mean scores of instrumental motivation as reported by the students.

Table 5. Descriptive Statistics of Instrumental Motivation Items

\begin{tabular}{|c|c|c|c|c|c|}
\hline & $\mathrm{N}$ & Minimum & Maximum & Mean & $\begin{array}{c}\text { Std. } \\
\text { Deviation }\end{array}$ \\
\hline $\begin{array}{l}\text { Learning English can be important for me because I will be able to } \\
\text { communicate with native speakers of English. }\end{array}$ & 51 & 3.00 & 5.00 & 4.5490 & .67272 \\
\hline $\begin{array}{l}\text { Learning English can be important for me because it will help me } \\
\text { to get an ideal job in the future. }\end{array}$ & 51 & 3.00 & 5.00 & 4.6667 & .65320 \\
\hline $\begin{array}{l}\text { Learning English can be important for me because I will need it } \\
\text { for my future career. }\end{array}$ & 51 & 3.00 & 5.00 & 4.6863 & .58276 \\
\hline $\begin{array}{l}\text { Learning English can be important for me because it will make me } \\
\text { a more knowledgeable person. }\end{array}$ & 51 & 2.00 & 5.00 & 4.2353 & .83877 \\
\hline $\begin{array}{l}\text { Learning English can be important for me because other people } \\
\text { will respect me more. }\end{array}$ & 51 & 1.00 & 5.00 & 3.0784 & 1.33930 \\
\hline $\begin{array}{l}\text { Learning English can be important for me because it will help me } \\
\text { to further my studies. }\end{array}$ & 51 & 2.00 & 5.00 & 4.5490 & .75667 \\
\hline $\begin{array}{l}\text { Learning English can be important for me because it will help me } \\
\text { search for information and materials in English on the Internet. }\end{array}$ & 51 & 2.00 & 5.00 & 4.3725 & .79902 \\
\hline $\begin{array}{l}\text { Learning English is important to me because it will help me when } \\
\text { I travel abroad. }\end{array}$ & 51 & 3.00 & 5.00 & 4.5686 & .64047 \\
\hline $\begin{array}{l}\text { I Learn English diligently because I want to earn a university } \\
\text { degree. }\end{array}$ & 51 & 1.00 & 5.00 & 4.5098 & .80926 \\
\hline $\begin{array}{l}\text { Learning English is important to me because it will help me to } \\
\text { achieve at school. }\end{array}$ & 51 & 1.00 & 5.00 & 4.2941 & 1.06384 \\
\hline Valid N (listwise) & 51 & & & & \\
\hline
\end{tabular}

As shown in Table 5, the students reported high mean scores of instrumental motivation towards learning English language. The highest mean scores were items 3, 2, 8 (i.e. learning 
English can be important for me because I will need it for my future career, learning English can be important for me because it will help me to get an ideal job in the future, and learning English is important to me because it will help me when I travel abroad). The lowest mean scores reported by the students were questions 5, 4, 10 (i.e. learning English can be important for me because other people will respect me more, learning English can be important for me because it will make me a more knowledgeable person, learning English is important to me because it will help me to achieve at school. Next section compares the level of motivation according to gender.

\subsection{Level of Motivation and Gender}

This section provides analysis to the third research question: Is there any statistical significant differences in the motivation towards learning English according to gender? The analysis procedures include means and standard deviations reported and by male and female students. Independent Samples T-Test were used to compare the means of motivation according to gender.

Table 6. Mean Scores of Motivation According to Gender

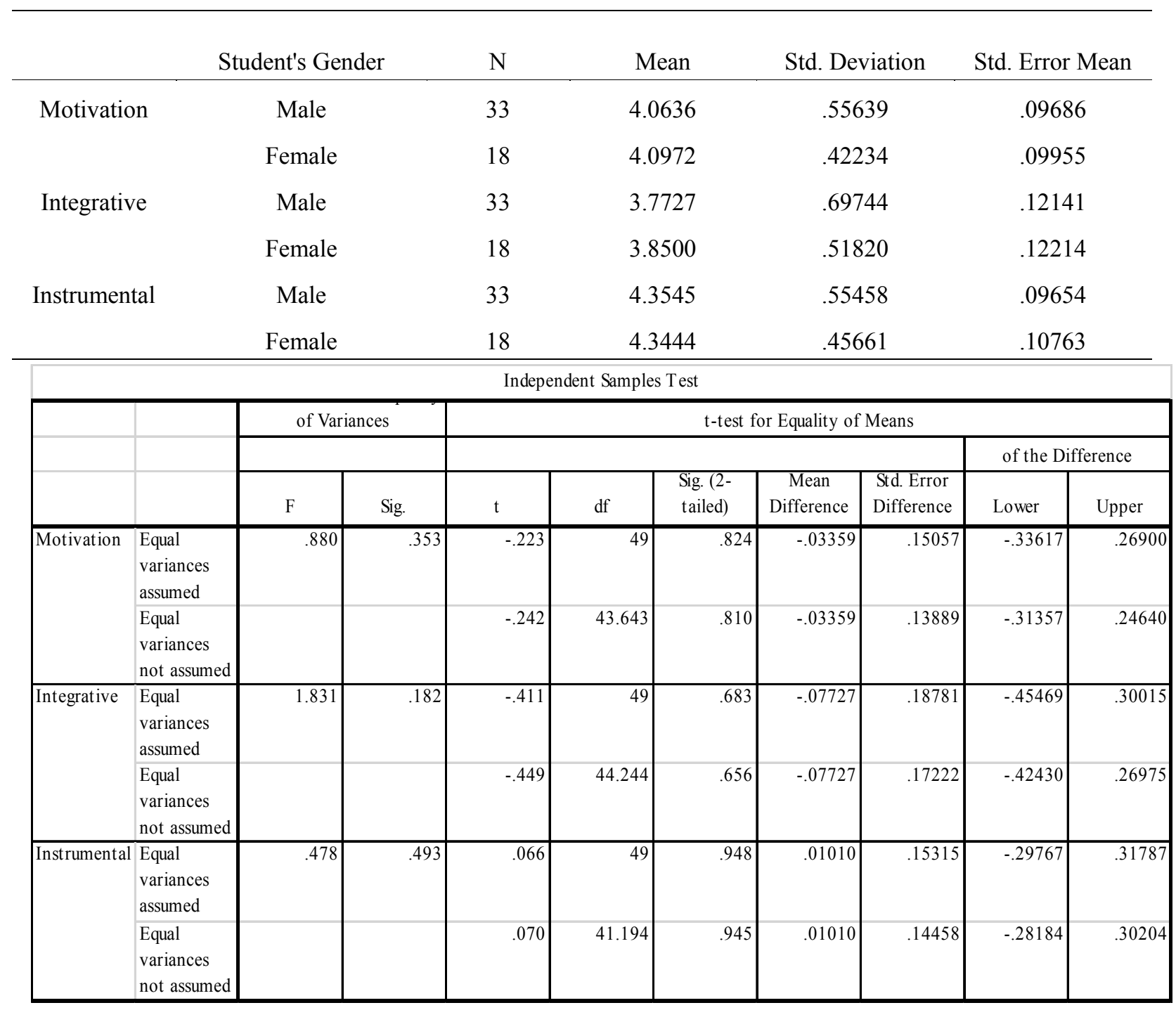


As revealed in the tables above, female students reported higher mean score compared to their male students counterparts $(M=4.09,4.06)$ respectively. Hence, it can be concluded that female students were more motivated towards learning English language than male students. However, there was no statistically significant differences in learning motivation with respect to gender as the level of significance was .353 which is higher than .05 . With respect to integrative motivation, female students scored higher means than male students $(M=3.85$, 3.77) successively. It can be said that female students were more integratively motivated towards learning English than male students. Nevertheless, there was no statistically significant differences between males and females in integrative motivation as the significance level was .182 which is also higher than .05. Interestingly, male students scored slightly higher mean than female students in instrumental motivation $(M=4.35,4.34)$ respectively. However, there was no significant differences between males and females with respect to instrumental motivation as the significance level was higher than .05 (sig. 493).

\section{Discussion}

The results of the present study indicate that Jordanian gifted school students were highly motivated towards learning English language. The results concur with other studies' results (Kitjaroonchai and Kitjaroonchai 2012; Tahaineh and Daana, 2013; Che Mat and Yunus, 2014). These studies found that students were highly motivated towards learning English language. It is apparent that the students are aware of the importance of English language, so they desire to learn and master their proficiency in English to succeed in all life fields. The results also revealed that the students reported higher instrumental motivation than the integrative one. This result confirms other researches results (Choosri and Intharaska, 2011; Che Mat and Yunus, 2014). One possible reason for such results might be related to the students' preference to maintain their identity. They may fear of losing their values and inherited traditions through integrating with foreign English societies. Another reason for this results might be attributed to the importance of learning English to get better job. The students reported learning English for several practical reasons such as getting better job, improving future career, and furthering higher study. Regarding the level of motivation and gender, the results showed that female students reported higher motivation compared to their male students counterparts. This results is consistent to some of the previous studies (Kobayashi, 2002; Dorneyi, 2005). Oxford (1995) indicates that, brain hemisphericity, socialization, and cognitive style may play a vital role in the differences between males and females in learning motivation. Kaylani (1996) attributed the fact that female students were more aware of English language learning to social reasons; the knowledge of English language among Jordanian girls increases their employability and marriage qualifications.

\section{Conclusion and Implications of the Study}

The findings of this study revealed that gifted students at Jordanian schools are highly motivated towards learning English language. The students reported higher scores of 
instrumental motivation than integrative one. The findings also showed that there was no statistically significant differences in the motivational level according to gender. Based on the aforementioned findings, it can be said that the students are aware of the importance of learning English language. The high level of integrative and instrumental motivations reported by the students can be an indication to this awareness. Therefore, several pedagogical implications can be obtained. Teachers of English language should take into consideration their students' perceptions about learning English and try to value those perceptions. Teachers should present the proper teaching materials and contents that suit the students' motivational orientations. In addition, teachers can help students in setting specific goals in language learning and assist in achieving these goals through providing the necessary feedback. Teaching English should not be for completing the syllabi only, rather, teaching English should be planned carefully to provide more meaningful learning experiences and maximize the chances of language engagement. These points and steps might lead to a more positive attitude and motivation which are extremely significant to succeed in language learning.

\section{References}

Agnihotri, R.K., \& Khanna, A.L. (1994). Second Language Acquisition: Socio-cultural and Linguistic Aspects of English in India. New Delhi/Thousand Oaks/London: Sage Publications.

Al-Bustan, S. A., \& Al-Bustan, L. (2009). Investigating students attitudes and preferences towards learning English at Kuwait University. College Student Journal, 43(2), 454-463.

Bader, Y. (1995). Code-switching to English in Daily conversations in Jordan: Facto and Attitudes. Abhath Al-Yarmouk Literature and Linguistics Series, 13(2), 9-2.

Brophy J (1998). Motivating Students to Learn. Madison, WI: McGraw Hill.

Brown, H.D. (2000). First language acquisition. In Principles of language learning and teaching ( $4^{\text {th }}$ ed.) (pp. 20-48). New York: Pearson Education.

Budak S (2003). Dictionary of Psychology. Bilim ve Sanat publishing. Ankara, Turkey.

Che Mat, S., \& Yunus, M. (2014). Attitudes and motivation towards learning English among FELDA school Students. Australian Journal of Basic and Applied Sciences, 8(5), 1- 8.

Choosri. C., \& Intharaksa, U. (2011). Relationship between motivation and students' English learning achievement: A study of the second year vocational certificate level Hatyai Technical College students. Retrieved: February 10, 2015 from http://sv.libarts.psu.ac.th/conference5/proceedings/Proceedings3/article//006.pdf

Crookes, G., \& Schmidt, R. W. (1991). Motivation: Reopening the research agenda. Language Learning, 41(4),

http://dx.doi.org/10.1111/j.1467-1770.1991.tb00690.x 
Dejnozka, E. L., \& Kapel, D. E. (1991). American Educators' Encyclopedia. Westport, Connecticut: Greenwood Press.

Dörnyei, Z. (2005). The psychology of the language learner: Individual differences in second language acquisition. Mahwah, NJ: Lawrence Erlbaum.

Dörnyei, Z., Csizér, K., \& Németh, N. (2006). Motivation, language attitudes, and globalization: A Hungarian perspective. Clevedon, UK: Multilingual Matters.

Dunn R, Griggs SA (1985). Teaching and counseling gifted students with their learning style preferences: Two case studies. Gifted Child Today, 41, 40-43.

Feldhusen J (1986). A conception of giftedness: conception of giftedness. In: Steinberg RJ, Davidson JE (Eds.), Conception of Giftedness. New York: Cambridge University press pp.112-128.

Gardner, R. (2006). The socio-educational model of second language acquisition: a research paradigm. EUROSLA Yearbook, 6, 237-260. http://dx.doi.org/10.1075/eurosla.6.14gar

Gardner, R. C. (1985). Social Psychology and Second Language Learning: The Role of Attitudes and Motivation. London: Edward Arnold.

Gardner, R. C., \& Lambert W. E. (1972). Attitudes and motivation in second language learning. Rowley, MA: Newbury House.

Gardner, R. C., \& Lambert, W. E. (1959). Motivational variables in second Language acquisition. Canadian Journal of psychology, 13, 266-272. http://dx.doi.org/10.1037/h0083787

Gardner, R. C., Smythe, P. C., \& Clément, R. (1979). Intensive second language study in a bicultural milieu: An investigation of attitudes, motivation and language proficiency. Language Learning, 29, 305-320. http://dx.doi.org/10.1111/j.1467-1770.1979.tb01071.x

Ghazvini, S. D., \& Khajehpour, M. (2011). Attitudes and motivation in learning English as a second language in high school students. Procedia Social and Behavioral Sciences, 15, 1209-1213. http://dx.doi.org/10.1016/j.sbspro.2011.03.264

Hazaymeh, O. (2004). The impact of bilingualism on ELT in Jordan. South Asian Language Review, $14(1+2), 24-32$.

Jafar, F. (2008). The Use of English in Internet Communication by Jordanian Students. $A l$ Basaer Journal, 12(2), 9-34.

Kachru, Y. (1992). World Englishes. Language learning and teaching 142(1). http://dx.doi.org/10.1017/S0261444800006583

Keller, J.M. (1983). Motivational design of instruction. In C.M. Reigeluth (Ed.). Instructional design theories and models: An overview of their current status. Hillsdale, NJ: Erlbaum. 
Kitjaroonchai, N., \& Kitjaroonchai, T. (2012). Motivation toward English language learning of Thai students majoring in English at Asia-Pacific International University. Catalyst, $7(1), 21-40$.

Kobayashi, Y. (2002). The role of gender in foreign language learning attitudes: Japanese female students' attitudes towards English learning. Gender and Education, 14(2), 181-197. http://dx.doi.org/10.1080/09540250220133021

Kokot S. (1999). Help Our Child is Gifted, Revision Edition. Redford House Publication, Henkos Printers (Pty) Ltd. Republic of South Africa.

Köktürk T. (2000). The importance of the comparison of teachers and students perceptions of motivational factors, 7th Workshop on Achievement and Task and Motivation and Earlisig: Motivation and Emotion, University of Leuven, Belgium.

Kyriacou, C., \& Zhu, D. (2008). Shanghai pupil's motivation towards learning English and the perceived influence of important others. Educational Studies, 34(2), 97-104. http://dx.doi.org/10.1080/03055690701811099

Lucas, R., Pulido, D., Miraflores, E., Ignacio, A., Tacay, M., \& Lao, J. (2010). A Study on the Intrinsic Motivation Factors in Second Language Learning Among Selected Freshman Students. The Philippine ESL Journal, 4, 3-23.

Maker CJ., \& Nielson AB. (1996). Curriculum development and teaching strategies for gifted learners (2nd ed.). Austin, TX: Pro-Ed.

Masgoret, A. M., \& Gardner, R. (2003). Attitudes, Motivation and Second Language Learning: A Meta-Analysis of Studies Conducted by Gardner and Associates. Language Learning, 53, 123-163. http://dx.doi.org/10.1111/1467-9922.00212

Noels A. N. (2001). Learning Spanish as a second language: Learners' orientations and their teachers' communication style. Language Learning, 51(1), 107-144. http://dx.doi.org/10.1111/0023-8333.00149

Oxford, R., \& Shearing, J. (1994). Language learning motivation: Expanding the theoretical $\begin{array}{lllll}\text { framework. Modern } \quad \text { Language } & \text { 12-28. }\end{array}$ http://dx.doi.org/10.1111/j.1540-4781.1994.tb02011.x

Polat, N. (2011). Gender and age differences in motivation and L2 accent attainment: An investigation of young Kurdish learners of Turkish. Language Learning Journal, 39, 19-41. http://dx.doi.org/10.1080/09571730903545251

Qashoa, S. (2006). Motivation among learners of English in the secondary schools in the eastern coast of the UAE. M.A thesis, British University in Dubai.

Ryan, S. (2009). Ambivalence and commitment, liberation and challenge: Investigating the attitudes of young Japanese people towards the learning of English. Journal of Multilingual and Multicultural Development, 30(5), 405-420. http://dx.doi.org/10.1080/01434630902928447 
Tahaineh, Y., \& Daana, H. (2013). Jordanian Undergraduates' Motivations and Attitudes towards Learning English in EFL Context. International Review of Social Sciences and Humanities, 4(2), 159-180.

Williams, M., Burden, R., \& Lanvers, U. (2002). French is the language of love and stuff: Student perceptions of issues related to motivation in learning a foreign language. British Research Journal, 28(4), 503-508. http://dx.doi.org/10.1080/0141192022000005805

Zahran, H. (1990). Socio-Psychology. Aalam Al-Kitaab for Publications and Distribution, Cairo, Egypt.

Zughoul, M.R. (2003). Globalization and EFL/ESL pedagogy in the Arab World. Learning a language, $1(2)$.

\section{Copyright Disclaimer}

Copyright for this article is retained by the author(s), with first publication rights granted to the journal.

This is an open-access article distributed under the terms and conditions of the Creative Commons Attribution license (http://creativecommons.org/licenses/by/3.0/). 